\title{
A clinical study on complications of chronic suppurative otitis media and level of awareness in patients admitted at tertiary care hospital in central India
}

\author{
Swapnil R. Pawar ${ }^{1}$, Yogesh Shukla ${ }^{2 *}$
}

${ }^{1}$ Department of E.N.T., N.S.C.B Medical College \& Hospital, Jabalpur, M.P., India
${ }^{2}$ Department of Community Medicine, N.S.C.B Medical College \& Hospital, Jabalpur, M.P., India

Received: 14 July 2015

Accepted: 18 July 2015

*Correspondence:

Dr. Yogesh Shukla,

E-mail: yogesh_shukla02@yahoo.com

Copyright: (C) the author(s), publisher and licensee Medip Academy. This is an open-access article distributed under the terms of the Creative Commons Attribution Non-Commercial License, which permits unrestricted non-commercial use, distribution, and reproduction in any medium, provided the original work is properly cited.

\section{ABSTRACT}

Background: Chronic suppurative otitis media (CSOM) is a common public health problem in India. Though there is decline in the incidence of complications but they are still frequent due to poor socio-economic conditions, lack of awareness about health care and availability of trained specialist in rural settings. The objective was to study the complications of CSOM and level of awareness in patients admitted at Department of E.N.T. N.S.C.B. Medical College \& Hospital Jabalpur M.P. India.

Methods: The present study comprises of 52 patients with complications secondary to CSOM admitted to the Dept. of E.N.T., N.S.C.B. Medical College Hospital Jabalpur M.P. India. An analysis was made regarding the demographic profile, clinical features, complications, awareness and the outcome of the study. Data was analysed with the help of Microsoft office excel.

Results: The total no. of 52 patients with complication of CSOM was included in the study. The most common age for complication was first three decade of life. Most of the patients belong to rural area and lower socioeconomic status. Majority of the patients presented with the history of ear discharge, headache, decreased hearing, ear ache, swelling behind the ear, fever, facial weakness \& signs of raised intracranial tension. Intratemporal complications was seen in $46(88.46 \%)$ of the patients while only $6(11.53 \%)$ belongs to intracranial complications. Overall awareness was poor. Self-medication was used in $23(44.23 \%)$ of cases and match stick with or without cotton was used in 31 $(59.61 \%)$ of patients for cleaning practice.

Conclusions: Complications of CSOM pose a great challenge in clinical practice \& Public health. Early intervention $\&$ awareness is required to decrease morbidity and mortality of the patients.

Keywords: Chronic suppurative otitis media, E.N.T., Level of awareness

\section{INTRODUCTION}

Chronic Suppurative Otitis Media (CSOM) is one of the most common diseases in clinical practice. In our country burden of the disease is too high considering the huge population. Prevalence of CSOM in the world is around 65-330 million/year. Majority of world CSOM burden is attributed by Southeast Asia, Western pacific and African countries. India falls into countries with highest prevalence (prevalence $>4 \%$ ). ${ }^{1}$ Though there is general decline in the incidence of complications, they are still frequently seen in our country. The causes are poor socioeconomic conditions, lack of education and awareness as middle ear discharge is still being considered a nuisance rather than a potentially dangerous conditions. The lack of availability of trained specialist is also a major concern. $^{2}$

CSOM is a disease condition characterized by persistent perforation of tympanic membrane with recurrent or persistent muco-purulent Otorrhoea. ${ }^{3}$ The duration of the 
Otorrhoea has been a subject of controversy among otolaryngologist with various definitions ranging from six weeks to three months from various studies. ${ }^{4,5}$ The complications of Otitis media are divided into two main groups. Intra temporal complications include mastoiditis, petrositis, facial paralysis and labyrinthitis. The intracranial complications include extradural abscess, subdural abscess, and meningitis and brain abscess.

Development of complications depends on high virulence of organism, poor resistance of patients, inadequate antibiotic treatment of acute middle ear and mastoid infection, presence of chronic systemic disease and resistance of organisms to antibiotics which is becoming common these days. ${ }^{1}$ Lack of awareness and ignorance further increases the chances of developing either extra cranial or intracranial complications. Complications of CSOM can be lethal if they are not identified and treated properly.

The present study was conducted to identify the clinical presentations of complication of CSOM and level of awareness in patients regarding these complications and utility of early clinical detection and the appropriate treatment modalities.

\section{METHODS}

Study setting: This cross sectional study was conducted at Department of E.N.T. N.S.C.B. Medical college Hospital Jabalpur (M.P) India.

Study period: 10 September 2010 to 9 September 2011

Inclusion criteria: All patients with intra temporal and intracranial complications who were diagnosed clinically or by CT scan were included.

Exclusion criteria: Cases without any complications, seriously ill and who were not interested to take part in the study.

Ethics Approval \& consent: Research was initiated after acceptance of the study by the ethical committee of the N.S.C.B. Medical College Jabalpur India for research. Informed written consent was taken from participants. During processing of the data, strict confidentiality was maintained.

Methodology: This cross sectional study was conducted at Department of E.N.T., N.S.C.B. Medical college Hospital, Jabalpur (M.P). The total no. of 52 patients with complication of CSOM admitted to department of E.N.T., was included for the study. A thorough history and detailed general, otolaryngological, neurological, ophthalmological, CT head and temporal bone was done. Selection of antibiotics and surgical procedure on ear was done as per the extent and type of disease. The neurological consultation was done for intracranial complication.

\section{RESULTS}

The total 52 patients with CSOM was included in the study. The total number of male was $29(55.76 \%)$ while the female was 23 (44.23\%). The most common age group with complication was 11-30 years. There was total no. of $20(38.47 \%)$ patients in this age group. This age group is followed by $12(23.07 \%)$ were $<10$ years, 9 $(17.30 \%)$ were between $51-70$ years, $6(11.54 \%)$ were > 71 years and $5(9.62 \%)$ were in the age group of $31-50$ years (Table 1).

Table 1: Distribution of complicated cases of CSOM according to age and sex.

\begin{tabular}{|lllllll|}
\hline \multirow{7}{*}{$\begin{array}{l}\text { Ag } \\
\text { e }\end{array}$} & \multicolumn{2}{c}{ Male } & \multicolumn{2}{c|}{ Female } & Total & \\
gro & $\begin{array}{l}\text { Num } \\
\text { ber }\end{array}$ & $\begin{array}{l}\text { Perce } \\
\text { ntage } \\
(\%)\end{array}$ & $\begin{array}{l}\text { Num } \\
\text { ber }\end{array}$ & $\begin{array}{l}\text { Perce } \\
\text { ntage } \\
(\%)\end{array}$ & $\begin{array}{l}\text { Numb } \\
\text { er }\end{array}$ & $\begin{array}{l}\text { Percen } \\
\text { tage } \\
(\%)\end{array}$ \\
\hline $\begin{array}{l}<10 \\
\text { yr }\end{array}$ & 7 & 24.13 & 5 & 21.74 & 12 & 23.07 \\
\hline $\begin{array}{l}11- \\
30 y\end{array}$ & 11 & 37.93 & 9 & 39.14 & 20 & 38.47 \\
r & & & & & & \\
\hline $\begin{array}{l}31- \\
50 y\end{array}$ & 3 & 10.34 & 2 & 8.69 & 5 & 9.62 \\
r & & & & & & \\
\hline $\begin{array}{l}51- \\
70 y\end{array}$ & 5 & 17.25 & 4 & 17.39 & 9 & 17.30 \\
r & & & & & \\
\hline $\begin{array}{l}>71 \\
\text { yr }\end{array}$ & 3 & 10.35 & 3 & 13.04 & 6 & 11.54 \\
\hline $\begin{array}{l}\text { Tot } \\
\text { al }\end{array}$ & 29 & 55.76 & 23 & 44.23 & 52 & 100 \\
\hline
\end{tabular}

The most of the patients $38(73.07 \%)$ with complication of CSOM belongs to rural area while only $14(26.93 \%)$ patients belongs to urban area (Table 2). The majority of patients $43(82.70 \%)$ belong to Hindu religion followed by $7(13.46 \%)$ belong to Muslim and $2(3.84 \%)$ belongs to Christian community (Table 3 ).

Table 2: Distributions of complicated cases of CSOM according to locality.

\begin{tabular}{|lll|}
\hline Locality & $\begin{array}{l}\text { Number } \\
\text { cases }\end{array}$ & $\begin{array}{l}\text { of } \\
\text { Percentage } \\
(\%)\end{array}$ \\
\hline Rural & 38 & 73.07 \\
\hline Urban & 14 & 26.93 \\
\hline Total & 52 & 100 \\
\hline
\end{tabular}

The most of the complicated cases $44(84.62 \%)$ of CSOM belongs to lower socioeconomic status followed by 6 $(11.54 \%)$ in middle while only $2(3.84 \%)$ belongs to upper socioeconomic status (Table 4). 
Table 3: Distributions of complicated cases of CSOM according to religion.

\begin{tabular}{|lll|}
\hline Religion & $\begin{array}{l}\text { Number } \\
\text { Cases }\end{array}$ & $\begin{array}{c}\text { of } \\
\text { Percentage } \\
(\%)\end{array}$ \\
\hline Hindu & 43 & 82.70 \\
\hline Muslim & 7 & 13.46 \\
\hline Christian & 2 & 3.84 \\
\hline Total & 52 & 100 \\
\hline
\end{tabular}

Table 4: Distribution of complicated cases of CSOM according to socioeconomic status.

\begin{tabular}{|lll|}
\hline $\begin{array}{l}\text { Socioeconomic } \\
\text { Status }\end{array}$ & $\begin{array}{l}\text { Number } \\
\text { Cases }\end{array}$ & $\begin{array}{c}\text { of } \\
\text { Percentage } \\
(\%)\end{array}$ \\
\hline Upper & 2 & 3.84 \\
\hline Middle & 6 & 11.54 \\
\hline Lower & 44 & 84.62 \\
\hline Total & 52 & 100 \\
\hline
\end{tabular}

The majority of cases $47(90.38 \%)$ presented with unilateral involvement of ear while only $5(9.62 \%)$ involved bilateral distribution (Table 5).

Table 5: Distribution of cases according to laterality of ear.

\begin{tabular}{|lll|}
\hline $\begin{array}{l}\text { Laterality } \\
\text { Ear }\end{array}$ & $\begin{array}{l}\text { Number } \\
\text { Cases }\end{array}$ & $\begin{array}{l}\text { of } \\
\text { Percentage } \\
(\%)\end{array}$ \\
\hline Unilateral & 47 & 90.38 \\
\hline Bilateral & 5 & 9.62 \\
\hline Total & 52 & 100 \\
\hline
\end{tabular}

Table 6: Distribution of patients according to frequency of presenting complaints in complicated case of CSOM $(\mathrm{N}=52)$.

\begin{tabular}{|ll|l|}
\hline S. No. & Variables & Frequency \\
\hline 1 & Otorrhoea(Ear discharge) & 52 \\
\hline 2 & Decreased Hearing & 26 \\
\hline 3 & Swelling behind ear & 23 \\
\hline 4 & Otalgia (Ear ache ) & 25 \\
\hline 5 & Vertigo & 04 \\
\hline 6 & Headache & 28 \\
\hline 7 & Fever & 18 \\
\hline 8 & vomiting & 03 \\
\hline 9 & Facial weakness & 13 \\
\hline 10 & $\begin{array}{l}\text { Signs of raised } \\
\text { intracranial tension }\end{array}$ \\
\hline 11 & Signs of meningitis \\
\hline
\end{tabular}

All the patients $52(100 \%)$ were presented with the history of otorrhoea (ear discharge). In 28 (53.84\%) patients showed the presenting complaints of headache followed by decreased hearing in $26(50 \%)$, otalgia (ear ache) in 25 (48.07\%), swelling behind the ear 23 $(44.23 \%)$, fever in 18 (34.61\%), facial weakness in 13 (25\%), signs of meningitis in $5(9.61 \%)$, vertigo in 4
(7.69\%), vomiting and signs of raised intracranial tension in $3(5.76 \%)$ of complicated cases of acute suppurative otitis media (Table 6).

The most of the patients $46(88.46 \%)$ belongs to Intratemporal complications while only 6 (11.53\%) belongs to intracranial complications (Table 7).

Table 7: Distribution of complication of CSOM according to site of involvement.

\begin{tabular}{|lll|}
$\begin{array}{l}\text { Distribution of } \\
\text { Complication }\end{array}$ & $\begin{array}{l}\text { Number } \\
\text { Cases }\end{array}$ & $\begin{array}{l}\text { of } \\
\text { Percentage } \\
(\%)\end{array}$ \\
\hline Intratemporal & 46 & 88.46 \\
\hline Intracranial & 6 & 11.53 \\
\hline Total & 52 & $100 \%$ \\
\hline
\end{tabular}

The most important complication in intratemporal region is mastoiditis in $28(60.87 \%)$ of cases followed by subperiosteal abscess in $21(45.64 \%)$ patients. In subperiosteal abscess post auricular abscess involved in $18(39.13 \%)$ of cases followed by Zygomaticotemporal in $2(4.34 \%)$ and $1(2.17 \%)$ in Bezolds abscess in neck. Sensorineural hearing loss was seen in $19(41.30 \%)$ of cases followed by Labyrinthitis \& facial palsy in 13 $(28.26 \%)$ of cases, post auricular fistula in $11(23.91 \%)$ of cases and petrositis in $1(2.17 \%)$ were intratemporal complications of CSOM (Table 8).

Table 8: Distribution of cases according to intratemporal complications $(\mathrm{N}=46)$.

\begin{tabular}{|lll|}
\hline $\begin{array}{l}\text { Intratemporal } \\
\text { Complications }\end{array}$ & $\begin{array}{l}\text { Number } \\
\text { Patients } \\
\text { (frequency) }\end{array}$ & $\begin{array}{l}\text { of } \\
\text { Ratio } \\
\text { Percentage }\end{array}$ \\
\hline $\begin{array}{l}\text { 1. Sensorineural } \\
\text { Hearing Loss }\end{array}$ & 19 & 41.30 \\
\hline $\begin{array}{l}\text { 2. Mastoiditis } \\
\text { 3. Subperiosteal }\end{array}$ & 28 & 60.87 \\
$\begin{array}{l}\text { Abscess } \\
\text { a) Post } \\
\text { auricular }\end{array}$ & 18 & 39.13 \\
$\begin{array}{l}\text { Abscess } \\
\text { b) }\end{array}$ & 2 & 4.34 \\
$\begin{array}{l}\text { Zygomaticot } \\
\text { emporal } \\
\text { c) Bezolds } \\
\text { (In Neck) }\end{array}$ & 1 & 2.17 \\
\hline $\begin{array}{l}\text { 4. Post auricular } \\
\text { Fistula }\end{array}$ & 11 & 23.91 \\
\hline 5. Labyrinthitis & 13 & 28.26 \\
\hline 6. Facial Palsy & 13 & 28.26 \\
\hline 7. Petrositis & 1 & \\
\hline
\end{tabular}

Out of 6 patients of intracranial complication meningitis was seen in $5(83.33 \%)$ patients while brain abscess was found to be associated in $1(16.66 \%)$ of cases. 
Table 9: Distribution of cases according to intracranial complications $(\mathrm{N}=6)$.

\begin{tabular}{|lll|}
\hline $\begin{array}{l}\text { Intracranial } \\
\text { Complications }\end{array}$ & $\begin{array}{l}\text { Number } \\
\text { Cases }\end{array}$ & $\begin{array}{l}\text { Percentage } \\
(\%)\end{array}$ \\
\hline 1. Meningitis & 5 & 83.33 \\
\hline 2. Brain Abscess & 1 & 16.66 \\
\hline
\end{tabular}

Table 10: Treatment seeking pattern of complicated cases of $\operatorname{CSOM}(\mathrm{N}=52)$.

\begin{tabular}{|c|c|c|}
\hline $\begin{array}{l}\text { Treatment } \\
\text { seeking pattern }\end{array}$ & $\begin{array}{ll}\text { No. } & \text { of } \\
\text { patients }\end{array}$ & $\begin{array}{l}\text { Percentage } \\
(\%)\end{array}$ \\
\hline Self-medication & 23 & 44.23 \\
\hline From quacks & 13 & 25.00 \\
\hline $\begin{array}{l}\text { Traditional } \\
\text { medical system }\end{array}$ & 11 & 21.15 \\
\hline $\begin{array}{ll}\begin{array}{l}\text { MBBS/ } \\
\text { surgeons }\end{array} & \text { ENT }\end{array}$ & 05 & 9.62 \\
\hline
\end{tabular}

Table 11: Table showing ear cleaning practice of complicated cases of CSOM ( $\mathrm{N}=52)$.

\begin{tabular}{|llll|}
\hline $\begin{array}{l}\text { Ear cleaning } \\
\text { practice }\end{array}$ & $\begin{array}{l}\text { No. } \\
\text { patients }\end{array}$ & $\begin{array}{l}\text { Percentage } \\
(\%)\end{array}$ \\
\hline $\begin{array}{l}\text { Match stick with } \\
\text { or without cotton }\end{array}$ & 31 & 59.61 \\
\hline Water & 17 & 32.69 \\
\hline Cotton ear buds & 04 & 7.70 \\
\hline $\begin{array}{l}\text { Ear cleaning } \\
\text { practice }\end{array}$ & $\begin{array}{l}\text { No. of } \\
\text { patients }\end{array}$ & $\begin{array}{l}\text { Percentage } \\
(\%)\end{array}$ \\
\hline
\end{tabular}

According to treatment seeking pattern of complicated cases of CSOM self-medication was used in $23(44.23 \%)$ of cases followed by $13(25 \%)$ patients used treatment prescribed by quakes, in $11(21.15 \%)$ patients took treatment by traditional medical system while only 05 $(9.62 \%)$ consulted MBBS/ ENT surgeons in the past.

According to ear cleaning practices of complicated cases of CSOM match stick with or without cotton was used in $31(59.61 \%)$ of cases followed by water used for cleaning purpose in 17 (32.69\%) of cases. Only 4 (7.07\%) patients used cotton ear bud for ear cleaning purpose in the past.

\section{DISCUSSION}

The present study was conducted to know the complications of chronic suppurative Otitis media and level of awareness in patients regarding complications admitted at Department of E.N.T Medical College Jabalpur. The total no. of 52 patients with complication of chronic suppurative Otitis media was included in the study. Male patients were affected more $29(55.76 \%)$ as compared to the female $23(44.23 \%)$. Similar results were obtained by the Hussain et al. ${ }^{6}$ and Bento et al. ${ }^{7}$. The complications were mostly seen in first thirty years of life similar results were obtained by other Studies like
Moustafa et al. (2009), Dubey et al. (2007), Agrawal et al. (2005) and Shamboul et al. (1992). ${ }^{8-10}$

The most of the patients $38(73.07 \%)$ with complication of CSOM belongs to rural are and $44(84.62 \%)$ to lower socioeconomic status this is due to fact that Poor living conditions, poor access to medical care, inadequate medical treatment, recurrent upper respiratory tract infections and nasal diseases have been recognized as risk factors for CSOM similar results were obtained by Arunabha et al were $60 \%$ of their patients were from low socio-economic class. ${ }^{11}$ Thus improving living conditions with better sanitation and good access to medical care can reduce the incidence of CSOM and its complications. ${ }^{12}$ The majority of patients $43(82.70 \%)$ belong to Hindu religion because Hindu is majority community in the study population.

The majority of cases $47(90.38 \%)$ were presented with unilateral involvement of ear. The reason for this difference is not clear. This agrees with other existing literature which had reported similar findings. ${ }^{13,14}$ The prevalence of unilateral disease is believe to be good as it proffers a better prognosis in limiting the risk of disability from accompany hearing loss than for bilateral disease.

The most common symptom was a long standing otorrhoea followed by descending order of frequency were headache, decreased hearing, Otalgia (ear ache), swelling behind the ear, fever, facial weakness, signs of meningitis, vertigo, vomiting \& signs of raised intracranial tension in complicated cases of acute suppurative Otitis media. Similar findings were in other studies. ${ }^{7,15}$

The most of the patients $46(88.46 \%)$ belongs to Intratemporal complications while only $6(11.53 \%)$ belongs to intracranial complications. The most important complication in Intratemporal region is mastoiditis in 28 $(60.87 \%)$ of cases followed by Subperiosteal abscess in $21(45.64 \%)$ patients. In Subperiosteal abscess post auricular abscess is seen in majority of the cases. Sensorineural hearing loss was seen in $19(41.30 \%)$ of cases followed by decreasing order of Labyrinthitis \& facial palsy, post auricular fistula and petrositis in Intratemporal complications of chronic suppurative Otitis media. Similar results were obtained by Moustafa et al. ${ }^{8}$, Grewal et al. (1994) ${ }^{16}$ as the most frequent complication was mastoiditis.

Out of 6 patients of intracranial complication meningitis was seen in $5(83.33 \%)$ patients followed by brain abscess. Meningitis is also found to be commonest intracranial complications in some of the studies. ${ }^{7,17}$ Other study found that brain abscess is the common complication. ${ }^{18}$

The overall awareness regarding problems associated with complications of CSOM was poor in patients. 
According to treatment seeking pattern of complicated cases of CSOM self-medication was used in $44.23 \%$ of cases followed by $25 \%$ patients used treatment prescribed by quakes, $21.15 \%$ patients took treatment by traditional medical system doctors while only $9.62 \%$ consulted MBBS/ ENT surgeons in the past. The high percentage of self-medication by the patients was due to wide spread availability of ear drops as over the counter products in our country. The rural and poor patients believe in quakes and other traditional system leading to complications of CSOM. According to ear cleaning practices of complicated cases of CSOM match stick with or without cotton was used in $31(59.61 \%)$ of cases followed by water used for cleaning purpose. Only 4 (7.07\%) patients used cotton ear bud for ear cleaning purpose in the past. The patients still lack the basic knowledge of cleaning practice of ear leading to problems of ear infections.

\section{CONCLUSION}

Complications of chronic suppurative Otitis media are a great concern for clinical practice \& public health. High level of awareness in patients regarding these complications and utility of early clinical detection and the appropriate treatment modalities are required to decrease the morbidity and mortality.

\section{Funding: No funding sources}

Conflict of interest: None declared

Ethical approval: Approved by Institutional Ethics

Committee

\section{REFERENCES}

1. Acuin J. Chronic suppurative otitis media-burden of illness and management options. Geneva: World Health Organization, 2004.

2. Dhingra PL. Diseases of ear, nose and throat. Elsevier publication New Delhi. Third edition, p. 97.

3. Ologe FE, Nwawolo CC. Prevalence of chronic suppurative otitis media among school children in a rural community in Nigeria. Nig Postgrad Med J. 2002;9:63-6.

4. Kenna MA. Treatment of chronic suppurative otitis media. Otolaryngol Clin North Am. 1994;27(3):457-72.

5. Goycoolea MV, Hueb MM, Ruah C. Definitions and terminology. Otolaryngol Clin North America. 1991;24(4):757-61.
6. Hussain A, Khan AR, Frequency of intra-cranial complications in chronic Otitis media J Ayub Med Coll Abottabad. 2005;17:75-7.

7. Bento R, De Brito R, Ribas GC. Surgical management of intracranial complications of otogenic infection. Ear Nose Throat J, 2006, 85;36-9

8. Moustafa BE, Fiky El, Sharnousy MM. Complications of Suppurative Otiitis Media: Still a problem in 21st century. J Otorhinolaryngol Head Neck Surg. 2009;71:87-92.

9. Agrawal S, Husein M, Mac Rae D. Complications of otitis media: an evolving state. J Otolaryngol. 2005; 34: S33-9.

10. KM. An unusual prevalence of complications of CSOM in young adults. $\mathrm{J}$ Otolaryngol. 1992;106:874-7.

11. Sengupta A, Anwar T, Ghosh D, Basak B. A study of surgical management of chronic suppurative otitis media with cholesteatoma and its outcome. Indian J Otolaryngol Head Neck Surg. 2010;62(2):171-76.

12. World Health Organisation. Prevention of hearing impairment from chronic otitis media. Report of a WHO/CIBA foundation workshop. Geneva. 1998.

13. Ologe FE, Nwawolo CC. Prevalence of chronic suppurative otitis media among school children in a rural community in Nigeria. Nig Postgrad Med J. 2002;9:63-6.

14. Ogisi FO, Awu OD. Screening audiometry in Nigerian school children. Nig J Paediatr. 1990; 17:49-53.

15. Rashid A, Khan RM, Ahmad I. Otogenic intracranial abscess. J Pak Med Assoc. 1992;42:2201.

16. Grewal DS. Otogenic abscess- our experience. Indian J Otolaryngol Head Neck Surg. 1995;47(2):106-12.

17. Gower D, Mc Gruit WF. Intracranial complications of acute and chronic infectious ear disease: A problem still with us. Laryngoscope. 1983;93:102833.

18. Memon MA, Matiullah S, Ahmed Z, Marafani MS. Frequency of un-safe chronic suppurative Otitis in patients with discharging ear. JLUMHS. 2008;1025 .

Cite this article as: Pawar SR, Shukla Y. A clinical study on complications of chronic suppurative otitis media and level of awareness in patients admitted at tertiary care hospital in central India. Int J Community Med Public Health 2015;2(3):223-7. 